\title{
Biological Activity of Methanolic Extract from Ganoderma lucidum, Momordica charantia, Fagopyrum tataricum, and Their Mixtures
}

\author{
Jae-Young Cha ${ }^{1}$, Jong-Sung $\mathrm{Jin}^{2}$ and Young-Su Cho ${ }^{3}$ \\ ${ }^{1}$ Technical Research Institute, Daesun Distilling Co., Ltd, Busan 619-951, Korea \\ ${ }^{2}$ Division of High-Technology Materials Research, Busan Center, Korea Basic Science Institute (KBSI), Busan 618-230, Korea \\ ${ }^{3}$ Department of Biotechnology, Dong-A University, Busan 604-714, Korea
}

Received April 11, 2011 /Revised June 10, 2011 /Accepted June 10, 2011

\begin{abstract}
The concentrations of bioactive material (polyphenolics and flavonoids) and the biological activities of antioxidative (DPPH [a, $a^{\prime}$-diphenyl- $\beta$-picrylhydrazyl] free radical scavenging activity, peroxidation of rat liver microsome, and $\mathrm{Fe} / \mathrm{Cu}$ reducing power), a-glucosidase inhibition, tyrosinase inhibition, and fibrinolytic activity were tested by in vitro experimental models using $70 \%$ methanolic extract from Ganoderma lucidum, Momordica charantia, Fagopyrum tataricum and their mixtures. The highest yield and the concentrations of polyphenolics and flavonoids were shown in the mixture extract. Mixture extract was shown to have the highest activities of a-glucosidase inhibition and tyrosinase inhibition, fibrinolytic, DPPH free radical scavenging, and $\mathrm{Fe} / \mathrm{Cu}$ reducing power in a concentration-dependent manner. From these results, mixture methanol extract was shown to have the most potent bioactive properties and to contain large amounts of biological materials such as polyphenolics and flavonoids. This mixture could be a good dietary supplement material candidate, such as for antidiabetic functional foods.
\end{abstract}

Key words : Ganoderma lucidum, Momordica charantia, Fagopyrum tataricum, a-glucosidase.

\section{서 론}

경제 수준의 향상으로 인한 식생활 패턴의 변화로 인해 발 병되는 질환의 형태에 있어서도 비만, 당뇨, 고혈압, 혈관계질 환, 암과 같은 만성 질환의 발병률이 계속 높아지는 추세에 있다. 최근에는 이를 바탕으로 질병 예방 및 치유 차원에서 만성 질환 관련 건강식품에 대한 일반인의 관심과 요구가 증 가하면서 다양한 형태의 건강기능식품들이 개발되어 왔고, 이 들의 생체조절기능이나 질병의 회복 또는 예방에 어느 정도 가능성이 있는 것으로 제시되었다[6,7,23]. 특히 당뇨병과 관련 하여 민간요법으로 혈당 강하에 효과가 있는 것으로 알려진 한방약재를 비롯한 자연 식품들이 많이 사용되어 왔으나 이에 관련된 이화학적 특성이나 생리활성 작용에 관련한 기초적인 근거는 부족한 실정이다[7,25]. 한방약재 또는 식물 중에 함유 된 고미 물질이 특히 당뇨병을 개선하는데 유익한 것으로 알 려져 있다[22,43]. 고미 성분을 나타내는 대표적인 것으로 영지 버섯에 함유된 ganoderan, ganoderic acid, lucidenic acid와 같은 있는 triterpenoid류가 다수 알려져 있다[23,44,52]. 또 다 른 고미성분을 함유한 것으로는 여주, 쓴메밀, 씀바귀, 머위, 소태나무 등이 알려져 있는데, 주로 항당뇨, 항고혈압, 항동맥 경화, 항암 및 간 기능 보호 효과 등 당뇨 또는 그 합병증과도

*Corresponding author Tel : +82-51-730-9201, Fax : +82-51-730-9188

E-mail : e996390@yahoo.co.kr
밀접한 관련성을 가지고 있다[27,43,50].

영지(Ganoderma lucidum Karsten)는 담자균류의 구멍장이 버섯과(Polyporaceae), 영지속에 속하는 버섯으로 일명 만년버 섯 또는 불로초라고도 불리며 전 세계적으로 널리 분포하고 있어 한약재료로 귀하게 사용 되는 버섯 중의 하나이다. 영지 자실체 추출물에서 당뇨, 고지혈증, 고혈압, 혈액순환에 효과 가 있으며, 항산화 작용이나 항암 효과를 가지는 성분은 주로 고미 성분에 기인 한다고 알려져 있다[15,22,37].

여주(bitter melon, Momordica charantia)는 박목, 박과의 덩 굴성 한해살이풀로서 식용, 관상용, 약용 등으로 널리 쓰이는 데, 특히 약용으로서 간 보호, 항종양 작용, 항산화 작용 등이 보고되고 있다[1,11]. 여주를 말리면 맛이 써서 열매는 고과(苦 瓜), 뿌리는 고과근(苦瓜根), 줄기는 고과등(苦瓜藤), 잎은 고과 엽(苦瓜葉), 꽃은 고과화(苦瓜化), 씨앗은 고과자(苦瓜子)로 구 분 된다. 특히 이 쓴맛 성분이 trinorcucurbitane, cucurbitane triterpenoids, charatin 등으로 당뇨병에 효과가 있는 것으로 보고 되었다[20,43,50].

메밀은 주로 일반 메밀인 단메밀(buckwheat seed, Fagopyrum esculentum)과 쓴메밀(tartary buckwheat seed, Fagopyrum tataricum)로 구분되며 우리나라와 중국에서는 단 메밀이 주로 재배되고 있다[13]. 쓴메밀은 메밀의 일종으로 식 물분류학적으로 마디풀과에 속하는 일년초로서 주로 해발 $2,000 \mathrm{~m}$ 이상의 중국, 네팔을 비롯한 히말라야 고산 지대에서 생활하는 소수민족이 재배하여 주식으로 사용되고 있다. 특히 
쓴메밀에는 암 예방과 치료에 필수적인 특수 영양 성분인 셀 렌(selenium)과 고혈압, 동맥경화, 고지혈증, 당뇨, 궤양성질환 등의 생활습관병을 예방하는 rutin을 비롯해 quercetin, isoquercetin, myricetin 등의 생리활성 성분이 많이 함유되어 있 다 $[18,30,56]$.

한편 혈당 강하 효과를 나타내는 Lactobacillus acidophilus, Lactobacillus casei, Lactobacillus GG 유산균이 당뇨 유발 실험 동물에서 혈당치를 낮추는 효과가 보고 된 바 있다[48,54]. 또 한 영지 등의 버섯 혼합 추출물을 첨가하여 제조한 버섯발효 유를 급여한 제 1 형 streptozotocin-유발 당뇨쥐 및 제2형 비만 형 당뇨쥐에서 체중 증가량이 감소하고 인슐린 생성 췌도세포 가 회복 됨으로서 혈당치가 낮아지는 효과도 보고된 바 있다 [6,23]. 이러한 항당뇨 효과는 버섯 추출물을 첨가하지 않은 일반 발효유보다 더 우수한 결과를 나타내어 유산균과 버섯 추출물의 상호 작용에 의한 시너지 효과에 기인한 것이라 하 였다. 영지, 표고, 느타리버섯 추출물은 장내 유산균총인 Bifidobacterium breve 균주의 성장을 촉진시키고 효소 활성에 도 영향을 준다는 연구 결과도 보고된 바 있다[19]. 따라서 항 당뇨 효과를 나타내는 영지버섯 외에 여주 및 쓴메밀 추출물 을 추가하여 유산균으로 발효 시킴으로서 항당뇨 효과가 더욱 상승되는 것을 기대 할 수 있으리라 본다.

본 실험에서는 영지버섯, 여주, 쓴메밀 및 이들의 혼합 시료 로부터 고미물질이 최대로 추출될 수 있는 $70 \%$ 메탄올 추출물 을 이용하여 항당뇨 건강기능식품 개발을 위한 기초 실험으로 일반 이화학적 특성과 생리활성작용에 대하여 검토하였다.

\section{재료 및 방법}

\section{시료의 추출 및 수율 측정}

영지버섯, 여주, 쓴메밀 및 이들 동량 혼합시료의 메탄올 추출물을 얻기 위하여 각각 건조된 분말 시료를 $70 \%$ 메탄 올 용매에 $3 \%(\mathrm{w} / \mathrm{v})$ 수준으로 첨가하여 상온에서 12시간씩 교반 하면서 3회 반복 추출하였다. 회수한 혼합 용액을 여과 지(Whatman No.2)로 여과시켜 얻은 여액을 rotatory vacuum evaporator로 감압 농축하여 용매를 제거시킨 후 freeze dryer로 동결건조 하여 분말 시료를 얻었다. 각 추출 물들의 수율(\%)은 추출액을 동결 건조시켜 건물 중량을 구 한 다음 추출액 조제에 사용한 원료 건물량에 대한 백분율 로 계산하였다.

\section{총 폴리페놀 함량 측정}

페놀성 화합물의 함량은 페놀성 물질이 phosphomolybdic acid와 반응하여 청색을 나타내는 원리를 이용한 Folin-Denis 법을 응용하여 측정하였다[47]. 즉, $0.1 \%(\mathrm{w} / \mathrm{v})$ 시료 용액 0.5 $\mathrm{ml}$ 에 Folin-ciocalteu's phenol reagent $2.5 \mathrm{ml}$ 를 첨가하여 잘 혼합하고 5 분간 실온에서 방치하였다. 정확히 5 분 반응시킨
후 $7.5 \% \mathrm{Na}_{2} \mathrm{CO}_{3} 2 \mathrm{ml}$ 를 가하여 혼합하고 $50^{\circ} \mathrm{C}$ 에서 5 분간 발색 시킨 후 spectrophotometer (HITACHI U-2900, Hitachi High-Technologies Co., Kyoto, Japan) $760 \mathrm{~nm}$ 에서 흡광도를 측정하였다. 이때 페놀성 화합물의 함량은 tannic acid를 0-500 $\mu \mathrm{g} / \mathrm{ml}$ 농도로 하여 시료와 동일한 방법으로 측정한 표준곡선 으로부터 계산하였다.

\section{플라보노이드 함량 측정}

Flavonoid 함량은 Jia 등[24]의 방법에 따라 측정하였다. 각 추출물 시료 $0.1 \%(\mathrm{w} / \mathrm{v})$ 시료 용액 $0.25 \mathrm{ml}$ 에 $1.25 \mathrm{ml}$ 의 정제 수와 $5 \% \mathrm{NaNO}_{2}$ 용액 $5 \mathrm{ml}$ 을 가하고, 5 분 후 $10 \% \mathrm{AlCl}_{3} \cdot 6 \mathrm{H}_{2} \mathrm{O}$ $0.15 \mathrm{ml}$ 를 잘 혼합한 후 spectrophotometer (HITACHI U-2900) $510 \mathrm{~nm}$ 에서 흡광도를 측정하였다. 이 때 플라보노이 드 함량은 표준 물질로서 (+)-catechin hydrate을 20-200 $\mathrm{\mu g} /$ $\mathrm{ml}$ 농도로 시료와 동일한 방법으로 측정하여 작성한 표준곡선 으로부터 계산하였다.

\section{a-Glucosidase 저해 활성 측정}

영지버섯, 여주, 쓴메밀, 이들 혼합시료 메탄올 추출물의 a -glucosidase 활성 저해 측정은 전보의 방법에 따라 측정하였 다[49]. 즉, $0.1 \mathrm{M}$ sodium phosphate buffer (pH 7.0) $250 \mu \mathrm{l}$, $20 \mathrm{mM}$ pNPG (pnitrophenyl-a-D-glucopyranoside) 기질 250 $\mu \mathrm{l}$, 그리고 반응구에는 $0.5 \mathrm{mg} / \mathrm{ml}$ 시료액 $250 \mu \mathrm{l}$ 첨가하고, 대조구에는 증류수를 $250 \mu \mathrm{l}$ 첨가하여 $37^{\circ} \mathrm{C}$ 에서 5 분간 반응시 킨 후 spectrophotometer (HITACHI U-2900) $405 \mathrm{~nm}$ 에서 흡 광도를 측정하였다. 그 후, Saccharomyces cerevisiae 유래 a -glucosidase $(0.075 \mathrm{U} / \mathrm{ml}) 250 \mu 1$ 를 첨가하여 $37^{\circ} \mathrm{C}$ 에서 15 분 간 반응시킨 후, $0.1 \mathrm{M}$ sodium carbonate buffer $2 \mathrm{ml}$ 를 첨가하 여 반응을 정지시키고 spectrophotometer (HITACHI U-2900) $405 \mathrm{~nm}$ 에서 흡광도를 측정 하였다. Acarbose $(0.1 \mathrm{mg} / \mathrm{ml})$ 는 positive control로 사용하여 a-glucosidase 저해 활성을 다음 과 같은 식에 의하여 계산하였다.

저해율 $(\%)=[1-($ 반응액 $\mathrm{OD}) /$ 대조구 OD]×100

\section{$\mathrm{DPPH}$ 법에 의한 항산화 활성 측정}

영지버섯, 여주, 쓴메밀, 이들 혼합시료의 메탄올 추출물의 항산화 활성은 Blois의 방법에 따라 측정하였다[4]. 즉 DPPH (a,a'-diphenyl- $\beta$-picrylhydrazyl) 용액은 $100 \mathrm{ml}$ 에탄올에 $\mathrm{DPPH} 16 \mathrm{mg}$ 을 녹인 후 증류수 $100 \mathrm{ml}$ 를 혼합하여 여과지 (Whatman filter paper NO. 2)로 여과시켜 만들었다. DPPH 용액 $5 \mathrm{ml}$ 에 $0.1,0.5$ 및 $1 \mathrm{mg} / \mathrm{ml}$ 시료 용액 $1 \mathrm{ml}$ 을 혼합하여 실온에서 30 분간 반응시킨 후 spectrophotometer (HITACHI U-2900) $528 \mathrm{~nm}$ 에서 흡광도의 감소를 측정하였다. 대조구인 시판 항산화제 BHT는 $0.05 \%$ 로 첨가하여 상기와 동일한 방법 으로 흡광도 감소를 측정하였다. DPPH free radical scaveng- 
ing activity는 시료 첨가구와 무첨가구의 흡광도차를 백분율 (\%)로 표시하였다.

$\mathrm{DPPH}$ free radical scavenging activity $(\%)=[1-(\mathrm{Abs} /$ Abc) $] \times 100$

Abc: Absorbance of control treatment at $528 \mathrm{~nm}$

Abs: Absorbance of sample treatment at $528 \mathrm{~nm}$

\section{$\mathrm{Fe} / \mathrm{Cu}$ 환원력 측정}

영지버섯, 여주, 쓴메밀, 이들 혼합시료의 메탄올의 $\mathrm{Fe}$-환원 력 측정은 $\mathrm{Zhu}$ 등의 방법에 따라 측정하였다[57]. 각 시료 추 출물 $0.1,0.5$ 및 $1 \mathrm{mg} / \mathrm{ml}$ 농도로 한 용액 $0.75 \mathrm{ml}$ 을 취하고, $0.2 \mathrm{M}$ sodium phosphate buffer ( $\mathrm{pH}$ 6.6) $1.25 \mathrm{ml}$ 및 1\% (w/v) potassium ferricyanide $\left[\mathrm{K}_{3} \mathrm{Fe}(\mathrm{CN})_{6}\right] 1.25 \mathrm{ml}$ 을 혼합하여 $50^{\circ} \mathrm{C}$ 에서 20 분간 진탕반응 시켰다. 이 반응액에 $10 \%$ trichloroacetic acid $(\mathrm{w} / \mathrm{v})$ 를 $1.25 \mathrm{ml}$ 가하여 acidified 시키고, 3,000 $\mathrm{rpm}$ 에서 20 분간 원심분리 시켰다. 상층액 $2.5 \mathrm{ml}$ 를 취하고 distilled water $2.5 \mathrm{ml}$ 및 $0.5 \%$ ferric chloride $\left(\mathrm{FeCl}_{3}\right) 0.5 \mathrm{ml}$ 를 혼합한 후 실온에서 10 분간 반응 시켜 spectrophotometer (HITACHI U-2900) $700 \mathrm{~nm}$ 에서 흡광도를 측정하였다. 한편, $\mathrm{Cu}$-환원력 측정도 각 시료 $0.1,0.5$ 및 $1 \mathrm{mg} / \mathrm{ml}$ 용액에 0.01 $\mathrm{M} \mathrm{CuCl}_{2}, 7.5 \mathrm{mM}$ ethnolic neocuprorine solution, $1 \mathrm{M}$ $\mathrm{NH}_{4} \mathrm{OAc}$ buffer를 혼합하여 상온에서 반응시킨 후 spectrophotometer (HITACHI U-2900) $420 \mathrm{~nm}$ 에서 흡광도를 측 정하였다. 이때 환원력 비교를 위하여 천연 항산화제 ascorbic acid와 합성 항산화제 $\mathrm{BHT}$ 를 각각 시료와 동일한 농도와 방법 으로 흡광도를 측정하였다.

\section{$\mathrm{Fe}^{++} /$ascorbate에 의해 유도된 항산화 활성 측정}

성장기의 정상 흰쥐 간 조직으로부터 microsome 분획을 조제 하였다. 간 microsome 분획을 이용한 항산화 활성은 Wong 등의 방법에 따라 측정하였다[53]. 간 microsome 분획 $0.1 \mathrm{ml}(1 \mathrm{mg} / \mathrm{ml}$ 단백질), 각 시료 추출물 $0.1,0.5$ 및 $1 \mathrm{mg} / \mathrm{ml}$ 농도 용액 $0.2 \mathrm{ml}, 50 \mathrm{mM}$ Tris- $\mathrm{HCl}$ buffer $(\mathrm{pH} 7.5) 1.5 \mathrm{ml}$, $0.1 \mathrm{mM}$ ascorbate $0.1 \mathrm{ml}$ 및 $5 \mathrm{mM} \mathrm{FeSO}_{4} 0.1 \mathrm{ml}$ 의 반응액을 잘 혼합한 후 $37^{\circ} \mathrm{C}$ 에서 1 시간 반응시켜 지질 과산화를 유도시 켰다. 이때 음성 대조구는 시료를 첨가시키지 않고 증류수를 첨가하였으며, 양성 대조구 $\mathrm{BHT}$ 는 $0.05 \%$ 농도로 사용하여 동 일한 방법으로 측정하였다. 1시간 반응 후 $3 \mathrm{M}$ trichloroacetic acid와 $2.5 \mathrm{~N} \mathrm{HCl}$ 의 혼합 용액 $0.5 \mathrm{ml}$ 를 가하고 $3,000 \mathrm{rpm}$ 으로 원심분리 한 후 그 상등액 $1 \mathrm{ml}$ 에 $0.67 \% \mathrm{TBA} 1 \mathrm{ml}$ 를 넣고 30 분 동안 가열하여 발색시켰다. 냉각 후 $3,000 \mathrm{rpm}$ 에서 원심 분리 하여 얻은 발색된 반응 상등액을 spectrophotometer (HITACHI U-2900) $535 \mathrm{~nm}$ 에서 흡광도를 측정하였으며, 지질 과산화의 억제율은 대조구의 흡광도에 대한 저해율(\%)로 비 교하였다.

\section{혈전용해 활성 측정}

영지버섯, 여주, 쓴메밀, 이들 혼합시료의 메탄올 추출물의 혈전용해 효소 활성은 fibrin plate 법[2]을 변형하여 lysed zone으로 측정하였다. Fibrin plate는 $0.06 \%$ fibrinogen (Sigma Co., St. Louis MO, USA) 을 $0.2 \mathrm{M}$ borate buffer ( $\mathrm{pH}$ 7.5)에 용해시킨 후 Petri dish에 $10 \mathrm{ml}$ 씩 분주하고 thrombin $(5,000$ unit) 40 unit를 균일하게 섞이도록 가하면서 균일한 두께의 fibrin clot를 형성시킨 후 실온에서 30분간 방치한 후 사용하 였다. 시료 분말을 증류수에 $1 \mathrm{mg} / \mathrm{ml}$ 농도로 만든 후 여과하 여 fibrin plate 상에 $50 \mu \mathrm{l}$ 씩 점적하여 $37^{\circ} \mathrm{C}$ 에서 3 시간 동안 반응시킨 후 생성된 용해면적을 측정하여 활성을 비교하였다. 대조구는 혈전용해 효소인 plasmin $(0.75 \mathrm{U} / \mathrm{ml})$ 을 사용하여 다음과 같은 방법으로 혈전용해 활성을 산출하였다.

Fibrinolytic activity $(\%)=($ 시료의 용해 면적/plasmin의 용 해면적) $\times 100$

\section{Tyrosinase 저해 활성 측정}

영지버섯, 여주, 쓴메밀, 이들 혼합시료의 메탄올 추출물의 tyrosinase 활성은 Masamoto 등의 실험 방법[38]을 약간 변형 하여 측정하였다. In vitro mushroom tyrosinase 저해 활성 측 정은 $2.5 \mathrm{mM}$ 3,4-dihydroxyphenylalanine (L-DOPA) $0.3 \mathrm{ml}$, 각 시료 추출물 $0.1,0.5$ 및 $1 \mathrm{mg} / \mathrm{ml}$ 용액 $0.05 \mathrm{ml}$ 및 $0.1 \mathrm{M}$ 인산완충용액 $(\mathrm{pH} 6.8)$ 을 혼합하여 $25^{\circ} \mathrm{C}$ 에서 preincubation 시 켰다. 여기에 1,380 units/ml mushroom tyrosinase (2,500 unit, Sigma, St. Louis MO, USA) $0.05 \mathrm{ml}$ 를 넣은 후 $25^{\circ} \mathrm{C}$ 에서 2분간 반응시키면서 spectrophotometer (HITACHI U-2900) $475 \mathrm{~nm}$ 에서 흡광도를 측정하여 계산하였다. 대조구는 시료가 들어있지 않는 용액을 사용하였고, 양성 대조구는 tyrosinase 저해제 또는 미백제로 알려진 kojic acid, ascorbic acid, arbutin을 사용하여 tyrosinase 활성 저해율(\%)은 다음의 공식에 의하여 산출하였다.

Tyrosinase 활성 저해율 $(\%)=100-[(\mathrm{A}-\mathrm{B}) / \mathrm{A}] \times 100$

$\mathrm{A}$ : 시료가 들어있지 않은 반응액의 $0.5 \sim 1$ 분 사이의 흡광도 차이

B: 시료가 들어 있는 반응액의 $0.5 ~ 1$ 분 사이의 흡광도 차이

\section{통계처리}

실험으로부터 얻어진 결과치는 one-way ANOVA 검정에 의한 평균치와 표준오차 $(\mathrm{mean} \pm \mathrm{SE})$ 로 표시하였다[17].

\section{결과 및 고찰}

\section{영지버섯, 여주, 쓴메밀 및 혼합 추출물의 수율}

영지버섯, 여주, 쓴메밀 및 이들 혼합 시료 메탄올 추출물의 추출 수율은 각각 $21.07,16.35,3.23$ 및 $37.96 \%$ 로 혼합 추출물 
에서 추출 수율이 가장 높았다(Table 1). 혼합 추출물에서 추출 수율이 높은 것은 영지버섯, 여주 및 쓴메밀이 모두 같은 농도 로 함유되어 있기 때문이다. 특히 쓴메밀 추출물의 수율이 $3.23 \%$ 로 상당히 낮았는데, $\mathrm{Kim}$ 등[30]은 쓴메밀의 $70 \%$ 에탄올 및 메탄올 추출물의 수율이 각각 $7.0 \%$ 및 $6.6 \%$ 로 본 실험 결과 보다 상당히 높은 것으로 보고하였다.

\section{폴리페놀 화합물의 함량}

식물에 존재하는 폴리페놀 화합물이나 플라보노이드는 일 반적인 식품에도 널리 분포되어 있어 천연 항산화제로 작용할 수 있다는 결과들이 다수 알려지고 있다[8]. 본 실험에 사용한 영지버섯, 여주, 쓴메밀 메탄올 추출물의 폴리페놀 화합물 함 량을 측정한 결과 $2.64,3.82$ 및 $10.87 \%$ 로 쓴메밀에서 가장 높 았다(Table 1). 그러나 이들 혼합 추출물의 폴리페놀 화합물은 $17.08 \%$ 로 이들 세 시료의 합과 비슷한 함량을 보였다. 식용식 물 중의 폴리페놀 화합물 함량을 분석한 결과를 보면 당귀 $1.48 \%$, 천궁 $1.57 \%$, 삼칠근 $0.41 \%$, 삼백초 $1.27 \%$, 황기 $1.33 \%$ 등은 대체로 낮은 함량을 보였으며, 감초 $3.64 \%$, 산수유 $3.23 \%$, 갈근 $5.98 \%$, 가시오가피 $6.96 \%$, 음양곽 $8.10 \%$ 로 높은 함량을 보여 시료간에 큰 차이가 있다고 하였다[28]. 본 연구자들에 의한 식물 중 폴리페놀 화합물 함량 분석 결과에서는 참당귀 뿌리 에탄올 추출물 $14.40 \%$ 및 잎과 줄기 혼합물 에탄올 추출 물 $14.99 \%$, 선학초 $2.83 \%$, 복분자 $10.06 \%$, 정향 $11.42 \%$ 함유한 것으로 보고하였다[10,24].

\section{플라보노이드 함량}

영지버섯, 여주, 쓴메밀 메탄올 추출물의 플라보노이드 함 량은 각각 $2.11,2.22$ 및 $4.61 \%$ 함량을 보였다(Table 1). 이들 혼합 추출물의 플라보노이드 함량은 $9.33 \%$ 로 이들 세 시료의 합과 비슷한 농도를 보여 폴리페놀 화합물과 동일한 결과를 나타내었다. 한방약재의 플라보노이드 함량을 분석한 결과를 보면 당귀 $0.72 \%$, 천궁 $0.81 \%$, 삼칠근 $0.59 \%$, 삼백초 $0.29 \%$, 황기 $0.18 \%$ 등은 대체로 낮았으며, 감초 $5.54 \%$, 가시오가피 $4.40 \%$, 음양곽 $3.80 \%$, 땅두릅 $1.13 \%$ 및 땅두릅잎 $1.54 \%$ 등은 대체로 높은 함량을 보였다[8,28]. 대부분의 식물체에서 poly-

Table 1. Extracted yield and the concentrations of polyphenolics and flavonoids in methanolic extract from Ganoderma lucidum (GL), Momordica charantia (MC), Fagopyrum tataricum (FT), and their mixtures

\begin{tabular}{lccc}
\hline & $\begin{array}{c}\text { Extracted } \\
\text { yield (\%) }\end{array}$ & $\begin{array}{c}\text { Polyphenolics } \\
\text { concentrations }(\%)\end{array}$ & $\begin{array}{c}\text { Flavonoids } \\
\text { concentrations }(\%)\end{array}$ \\
\hline GL & $21.07 \pm 0.22$ & $2.64 \pm 0.10$ & $2.11 \pm 0.22$ \\
MC & $16.35 \pm 0.56$ & $3.82 \pm 0.28$ & $2.22 \pm 0.15$ \\
FT & $3.23 \pm 0.11$ & $10.87 \pm 0.06$ & $4.61 \pm 0.06$ \\
Mixture & $37.96 \pm 0.10$ & $17.08 \pm 0.14$ & $9.33 \pm 0.06$ \\
\hline
\end{tabular}

Values are mean $\pm S D, n=3$. phenolic compounds 함량이 flavonoids 보다 많이 함유 되어 있으며, 대체로 polyphenolic compounds 함량이 많은 식물이 flavonoid 함량도 많이 함유하고 있는 것으로 알려져 있다 $[14,28]$.

\section{a-Glucosidase 저해 활성}

a-glucosidase는 소장 상피세포의 brush-border membrane 에 존재하는 소화 효소로 a-amylase에 의해 분해된 다당류를 최종 단당류로 가수분해시켜 주는 역할을 하며, a-glucosidase 활성 저해는 탄수화물 식사 후 가수분해와 흡수과정을 지연시 킴으로서 당뇨 환자에서 식후 혈당치 상승을 감소시켜 줄 수 있다[36,45]. 따라서 a-glucosidase 활성 저해제는 제 2형 당뇨 와 같은 당질 관련 질병을 위한 치료제 개발에 매우 유용하게 이용되는 방법이다. 본 실험에서 positive control로 사용된 a -glucosidase 저해제인 acarbose는 $0.1 \mathrm{mg} / \mathrm{ml}$ 농도에서 $69 \%$ 의 저해 효과를 보였다. 또한 영지버섯, 여주, 쓴메밀 및 그 혼합 메탄올 추출물의 a-glucosidase 저해 활성은 각각 75,65 , 56 및 $78 \%$ 로 영지버섯과 혼합 추출물은 당뇨치료제인 acarbose보다는 약간 높은 저해 활성을 보였다(Fig. 1). 혼합 추출 물은 a-glucosidase 저해 활성이 가장 높아 탄수화물의 소화 과정에서 a-glucosidase에 의한 단당류 생성을 저해함으로써 식후 혈당의 급격한 상승을 막을 수 있는 천연물 유래 $a$ -glucosidase 활성 저해제로써 활용 가치가 있는 것으로 판단 된다. Kim 등[30]은 쓴메밀 추출물의 a-glucosidase 활성을 측 정 한 결과 $70 \%$ 에탄올 및 메탄올 추출물에서는 농도 의존적 으로 저해 활성이 높아지는 경향을 보였으나, 물 추출물에서 는 저해 활성이 없다고 하였다. 항산화 물질인 quercetin은 a -glucosidase를 가역적으로 느리게 결합하고, 비경쟁적인 저 해를 하는 것으로 나타나[33], 쓴메밀 $70 \%$ 에탄올 및 메탄올 추출물의 a-glucosidase 저해 활성 효과는 쓴메밀에 많이 함유

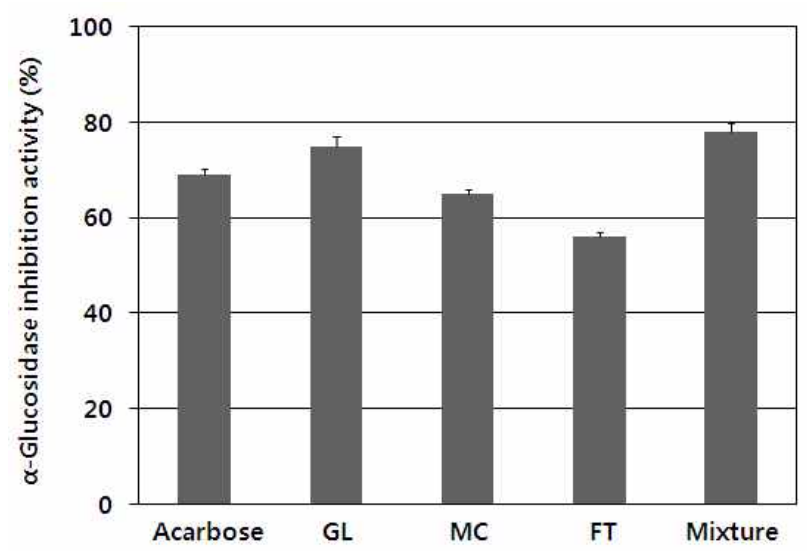

Fig. 1. a-Glucosidase inhibition activity of methanolic extract from Ganoderma lucidum (GL), Momordica charantia (MC), Fagopyrum tataricum (FT), and their mixture. Values are mean $\pm S D, n=3$. 
된 quercetin에 의한 것으로 시사된 바 있다.

\section{DPPH free radical scavenging 활성}

$\mathrm{DPPH}$ 는 비교적 안정한 free radical로써 식물 추출물의 항 산화 활성을 간단히 측정할 수 있는 동시에 실제 항산화 활성 과도 연관성이 매우 높기 때문에 많이 이용되고 있다 $[4,10,42]$. 모든 시료의 추출물에서 사용한 DPPH free radical scavenging 활성은 사용된 시료의 범위 내에서 처리 농도 증가와 함께 항산화 활성도 농도 의존으로 증가되는 경향을 보였으며, 대 조구로 사용한 BHT 및 ascorbic acid도 동일한 경향을 나타내 었다(Fig. 2). 쓴메밀 추출물 $0.1 \%$ 농도 처리에서 DPPH free radical 소거 활성은 $81.1 \%$ 로 상당히 높았는데, 동일 량을 처리 한 혼합 추출물에서 항산화 활성이 높았던 것도 쓴메밀에 기 인하는 것으로 사료되어진다. 특히 혼합 추출물의 $0.1 \%$ 농도 처리에서 항산화 활성은 시판 항산화제인 BHT 및 ascorbic acid와 거의 유사한 결과를 나타낼 정도로 높은 항산화 활성을 보였었다. 그러나 $\mathrm{Kim}$ 등[30]은 쓴메밀 메탄올 추출물의 $\mathrm{DPPH}$ free radical 소거 활성의 $\mathrm{RC}_{50}$ 값이 $34.0 \mathrm{\mu g} / \mathrm{ml}$ 으로 시판 항산화제 BHT $2.6 \mu \mathrm{g} / \mathrm{ml}$ 및 ascorbic acid $6.3 \mu \mathrm{g} / \mathrm{ml}$ 에 비해서는 상당히 낮은 것으로 보고하였다. 한편 $0.1 \%$ 영지버 섯 메탄올 추출물의 DPPH free radical 소거 활성이 $11.19 \%$ 로 상당히 낮았는데, 이는 영지버섯 물 추출물 $0.1 \%$ 농도에서 약 $30 \%$ 정도로 ascorbic acid보다 100배 정도 활성이 낮았다고 하는 결과와 유사하였다[44]. 한방약재인 당귀 $(15.8 \%)$, 갈근 $(16.8 \%)$, 감초 $(13.3 \%)$, 사상자 $(20.3 \%)$, 산약 $(9.6 \%)$, 삼칠근 $(2.6 \%)$, 오미자 $(33.5 \%)$, 옥죽 $(2.5 \%)$, 하수오 $(6.5 \%)$, 인삼 $(2.5 \%)$, 황정 $(3.2 \%)$ 에서는 대체로 낮은 항산화 활성을 보였으나, 산수 유 $(66.7 \%)$, 오가피 $(71.8 \%)$, 음양곽 $(69.5 \%)$ 과 같은 한방약재는 상당히 높은 항산화 활성을 보여 각 약재간에 많은 차이가 있었다[28]. 특히 항산화 활성이 높은 산수유, 오가피, 음양곽 과 같은 한방약재에는 폴리페놀 및 플라보노이드 함량이 상당

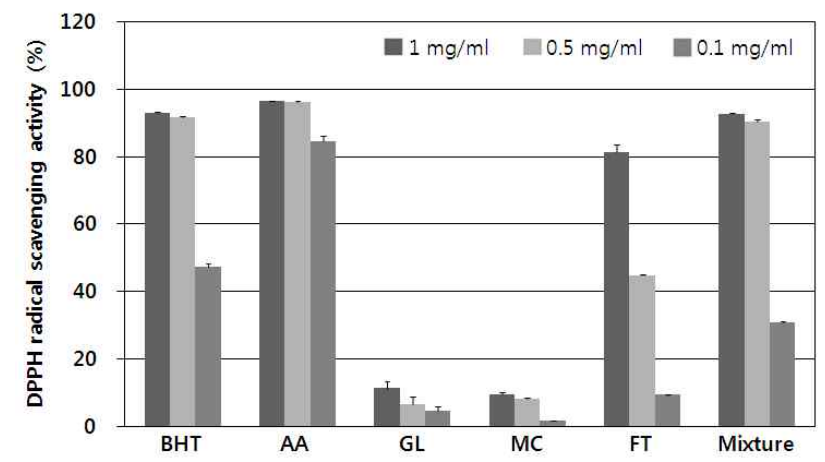

Fig. 2. DPPH radical scavenging activity of methanolic extract from Ganoderma lucidum (GL), Momordica charantia (MC), Fagopyrum tataricum (FT), and their mixtures. Values are mean \pm SD, $n=3$. BHT: butylated hydroxytoluene, AA: ascorbic acid.
히 많이 함유되어 있을 뿐만 아니라 폴리페놀 함량이 플라보 노이드 함량보다 훨씬 많이 함유하고 있어 식물 중에 존재하 는 다른 폴리페놀 화합물들이 항산화 활성을 나타내는 것으로 사료 되어진다[28]

\section{환원력 효과}

$\mathrm{Fe}$ 또는 $\mathrm{Cu}$ 환원력에 의한 항산화 반응은 수소 원자를 제공 하는 유리 라디칼의 연쇄 반응이며, 과산화 반응에서 일정한 전구물질과 반응하여 과산화 물질의 형성을 방해하는데 환원 력의 효과는 반응 물질의 흡광도 수치가 높을수록 환원력의 세기가 높다는 것을 나타낸다[53]. 영지버섯, 여주, 쓴메밀 및 혼합 메탄올 추출물의 $\mathrm{Fe}$ 환원력은 모두 처리 농도 증가와 함께 활성이 증가하는 경향을 보였다(Fig. 3). 특히 쓴메밀 추 출물의 경우 $\mathrm{Fe}$ 환원력이 동일 농도로 처리한 대조구 $\mathrm{BHT}$ 보다 환원력 효과가 높았다.

$\mathrm{Cu}$ 환원력의 경우도 영지버섯, 여주, 쓴메밀 및 혼합 메탄 올 추출물 모두 처리 농도 증가와 함께 높아지는 것으로 나타 났다(Fig. 4). 이 때 대조구로 BHT 및 ascorbate의 경우 Fe 환원 력 보다는 $\mathrm{Cu}$ 환원력의 활성이 더 높았으며, 본 실험에 사용한 시료 역시 대조구와 동일한 경향을 보였다.

\section{간장 microsome의 지질 과산화 억제활성}

지질 과산화 반응은 여러 가지 독성 화학물, 약물, 각종 질병 등 생체 이상에 의해 간세포에 중대한 손상을 입히는 것으로 알려져 있는데, 이러한 기전은 조직 내 세포의 산화적 스트레 스 증가 또는 항산화적 방어력의 감소로 인해 일어나게 되며, 생체 내에서 퇴행성 과정을 거쳐 질환을 유발하거나 노화를 촉진 시키는 원인으로 알려져 있어, 생체 내에서 지질 과산화 물의 제어는 매우 중요하다[3]. 동물 체내에서 생체막 지질의 과산화물 생성 정도를 나타내는 TBARS 함량 측정은 주로 간

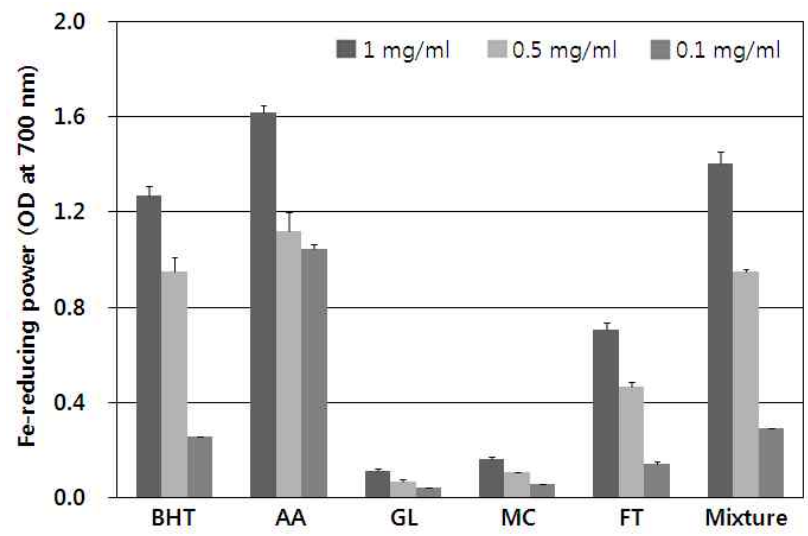

Fig. 3. Fe-reducing power of methanolic extract from Ganoderma Iucidum (GL), Momordica charantia (MC), Fagopyrum tataricum (FT), and their mixtures. Values are mean $\pm \mathrm{SD}, \mathrm{n}=3$. BHT: butylated hydroxytoluene, AA: ascorbic acid. 


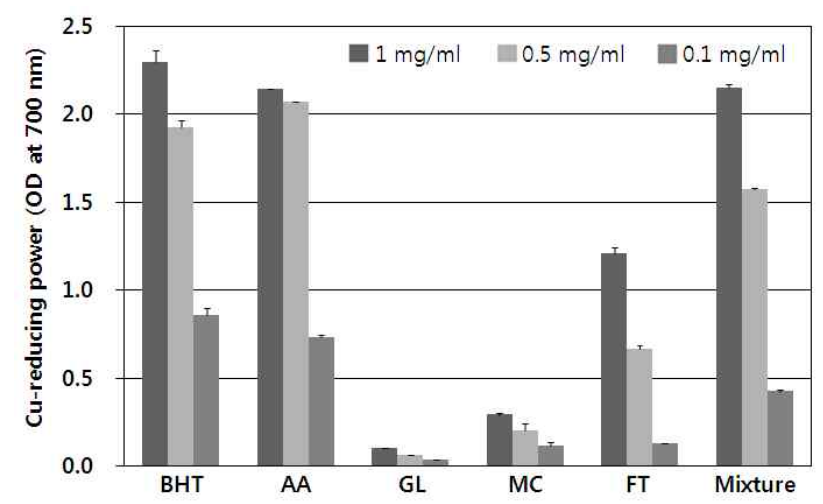

Fig. 4. Cu-reducing power of methanolic extract from Ganoderma lucidum (GL), Momordica charantia (MC), Fagopyrum tataricum $(\mathrm{FT})$, and their mixtures. Values are mean $\pm \mathrm{SD}, \mathrm{n}=3$. BHT: butylated hydroxytoluene, AA: ascorbic acid.

조직의 mitochondria 및 microsome 분획을 사용하여 $\mathrm{Fe}^{++}$/ ascorbate을 첨가하여 비효소적으로 유도하는데, 흰쥐 간 조직 에서 유발되는 과산화지질의 측정은 생체 산화 스트레스를 검토한다는 의미뿐만 아니라 다른 항산화 활성 측정법에 비하 여 보다 시간이 단축되는 이점이 있어 많이 사용되고 있다 [15,37]. 영지버섯, 여주, 쓴메밀 및 혼합 메탄올 추출물의 흰쥐 간 조직 microsome 분획의 TBARS 함량을 측정한 결과는 Fig. 5 와 같다. 영지버섯, 여주, 쓴메밀 및 혼합 메탄올 추출물의 TBARS 함량에 미치는 영향은 시료 처리 농도가 증가함에 따 라 지질과산화 억제 효과도 높아졌으나, 각 시료에 따른 큰 차이는 없는 것으로 나타났다. Chung [15]은 rat liver homogenate를 이용하여 영지버섯 메탄올 추출물 $2 \mathrm{mg}$ 을 처하였을 때 TBA값이 $54.6 \%$ 라 하여 본 실험 결과보다는 낮은 활성을 보였다. 또한 Lee 등[35]은 영지버섯 열수 추출물 $12.5,25$ 및 $50 \mu \mathrm{g} / \mathrm{ml}$ 농도 처리에서 에탄올-유발 간 조직 TBARS 값이

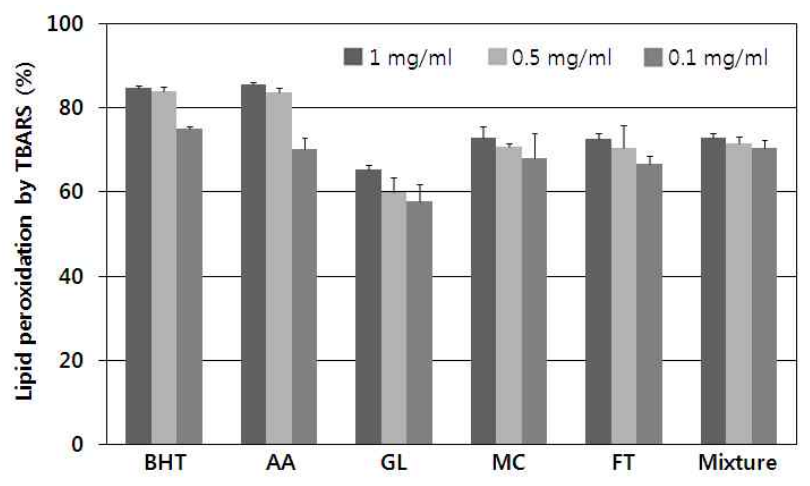

Fig. 5. Antioxidant activity of methanolic extract from Ganoderma lucidum (GL), Momordica charantia (MC), Fagopyrum tataricum (FT), and their mixtures on lipid peroxidation using rat liver microsome as measured by TBARS method. Values are mean $\pm S D, n=3$. BHT: butylated hydroxytoluene, AA: ascorbic acid.
농도 의존적으로 유의적인 감소를 하였다고 보고하였다.

\section{혈전용해 활성}

혈관에 혈전이 만들어지게 되면 혈액순환을 방해하여 고혈 압, 동맥경화, 뇌졸중, 협심증 등을 일으키는데, 이 때 혈전 용해 효소가 활성화되면 혈전 생성이 억제되어 각종 순환기계 질병을 예방하는데 효과가 있다고 알려져 있다[16]. 자연계에 존재하는 Bacillus subtilis 등의 미생물 유래나 청국장, 된장, 멸치젓갈, natto 및 shiokara (katauwokinase)와 같은 발효식 품 유래의 혈전용해제 개발은 다양하게 이루어져 왔다 $[29,46]$. 그러나 일부 천연물 유래의 항혈 전 효능은 극히 일부 소재에 국한되어 있는데, 단삼 메탄올 추출물[55], 팥과 녹두[39], 누에 분말[9] 등에서 그 효능이 밝혀져 있다.

본 실험에 사용한 영지버섯, 여주, 쓴메밀 및 혼합 추출물에 서도 항혈전 작용이 모두 있는 것으로 나타났으며, 각 시료들 간에 그 활성 차이는 크지 않았지만 혼합 추출물에서 가장 높은 활성을 보였다(Fig. 6). 대조구인 plasmin $0.75 \mathrm{U} / \mathrm{ml}$ 와 비교 했을 때 영지버섯, 여주, 쓴메밀 및 혼합 추출물 모두 fibrin 분해 활성이 모두 높은 것으로 나타났다. 또한 뽕나무버 섯(Armillariella mellea), 할미송이버섯(Tricholoma saponaceum), 신령버섯(Agaricus blaze) 및 차가버섯(Inonotus obliquus) 등의 버섯 균사체 또는 자실체 추출물에도 항혈전 작용이 있는 것 으로 알려져 있는데 그 활성은 높지 않았다고 하였다[31,32, 41].

\section{Tyrosinase 저해 활성}

멜라닌은 피부, 머리카락, 눈동자 등 체내에 널리 분포되어 있는 색소 성분으로 표피층의 색소세포 melanocyte의 melanosome에서 생합성 되는데, tyrosine을 시발 물질로 하여 tyrosinase 효소에 의해 DOPA (3,4-dihydroxy-phenylalanine)

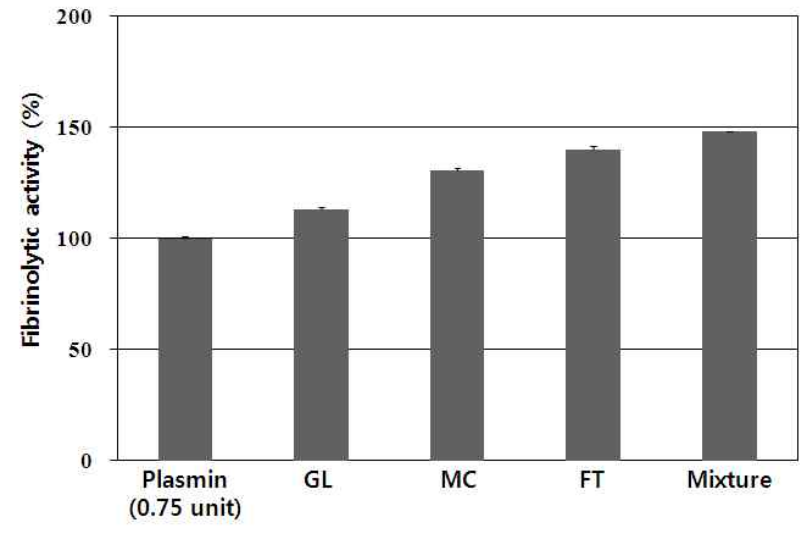

Fig. 6. Fibrinolytic activity of methanolic extract from Ganoderma lucidum (GL), Momordica charantia (MC), Fagopyrum tataricum (FT), and their mixtures. Values are mean $\pm \mathrm{SD}, \mathrm{n}=3$. Fibrinolytic activity $(\%)=($ lysed area of test sample solution/lysed area of control $) \times 100$. 
또는 DOPA quinone으로 산화 및 중합 반응에 의해 멜라닌이 만들어 진다[51]. 이때 생성되는 멜라닌이 자외선과 같은 피부 자극에 대해 저항력을 높여주기도 하지만 과도한 멜라닌 생성 은 기미, 주근깨, 검버섯과 같은 색소 침착과 피부 손상을 일으 키는데, tyrosinase 저해 활성 측정은 피부 미백 효과를 가진 생리활성물질의 탐색에 매우 유용한 연구 방법으로 평가 받고 있다[5]. 멜라노마 세포 증식과 멜라닌 생합성을 억제시키는 대표적인 화합물 중에 phenolic 화합물, flavonoid, arbutin, glycolic acid, kojic acid, pentadecenoic acid, ferulic acid, isoflavonoids 등이 제시되고 있다 $[5,26,33]$. 본 실험에 사용된 영 지버섯, 여주, 쓴메밀 및 혼합 추출물에도 많은 량의 폴리페놀 화합물과 플라보노이드 성분이 함유되어 있어 tyrosinase 저 해 활성이 높을 것으로 예상 되어진다. 본 실험에서 기존 미백 제로 알려진 kojic acid, ascorbic acid, arbutin처리에 의해서는 각각 77,67 및 $66 \%$ 의 비교적 높은 tyrosinase 저해 활성을 나타내었다(Fig. 7). 각 시료 추출물에 의한 tyrosinase 저해 활성은 $20 \%$ 이하의 비교적 낮은 활성을 보였다(Fig. 7). 그러나 Chien 등[12]은 영지버섯 $70 \%$ 에탄올, $50 \%$ 에탄올 및 물 추출 물 $1 \mathrm{mg} / \mathrm{ml}$ 농도에서 mushroom tyrosinase 활성 저해가 모 두 $80 \%$ 정도로 높았으며, $70 \%$ 에탄올 및 물 추출물 $0.1 \mathrm{mg} / \mathrm{ml}$ 의 낮은 농도에서도 약 $40 \%$ 의 저해 활성을 보여 본 실험 결과 와는 일치하지 않았다. 이러한 차이는 추출에 사용한 용매에 의한 것으로 사료된다. Basidiomycetes에 속하는 Antrodia cinnamomea 및 Agaricus blazei 버섯의 $70 \%$ 에탄올 추출물에서 mushroom tyrosinase 저해 활성이 가장 높았으며, Cordyceps militaris 버섯에서는 물 추출물이 다른 용매 추추물보다 높은 것으로 나타나 각 추출 용매에 따라 저해 활성에 많은 영향을 미치는 것으로 나타났었다[12].

국내에서 미백 화장품 원료로 사용되고 있는 한방 생약제에 관한 문헌을 근거로 한 티로시나제 저해 활성 정도는 메탄올 추출물인 갈근 $25 \%$, 후박 $3 \%$ 였으며, 에탄올 추출물인 창출

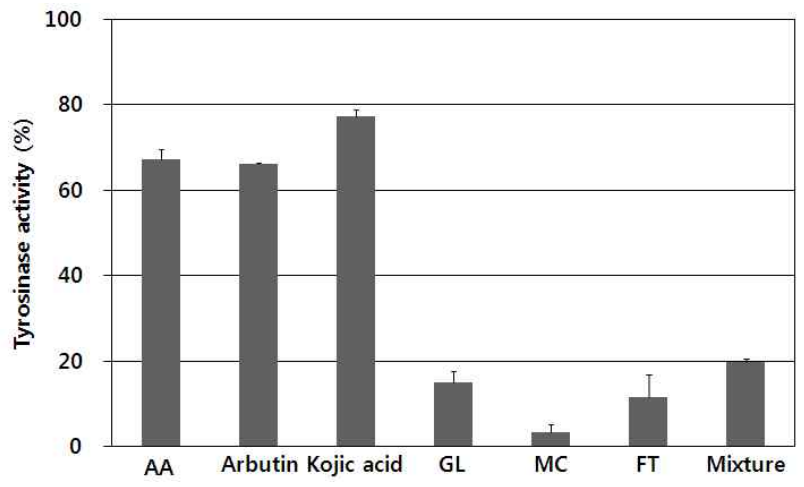

Fig. 7. Tyrosinase inhibition activity of methanolic extract from Ganoderma lucidum (GL), Momordica charantia (MC), Fagopyrum tataricum (FT), and their mixtures. Values are mean $\pm S D, n=3$. AA: ascorbic acid.
$14 \%$, 갈근 $10 \%$ 및 수용성 추출물인 함초 $42 \%$, 상백피 $63 \%$, 감초 $13 \sim 52 \%$, 작약 $44 \%$, 당귀 $39 \%$, 천궁 $28 \%$, 복령 $5 \%$ 로 비교 적 낮은 저해 활성을 나타내고 있다[26]. 이전의 실험에서 당귀 잎+줄기 및 뿌리의 에탄올 추출물에서 tyrosinase 저해 활성이 각각 $23.60 \%$ 및 $26.34 \%$ 였으며[21], 감초 $67.29 \%$, 복분자 $65.37 \%$, 상백피 $68.23 \%$ 로 상당히 높은 저해 활성을 가진 것으 로 나타났다[10].

이상의 실험에서 영지버섯, 여주 및 쓴메밀의 혼합 메탄 올 추출물에 폴리페놀 화합물과 플라보노이드가 많이 함유 되어 있어 높은 a-glucosidase 저해 활성, 항산화 활성, 환원 력, 항혈전 작용과 티로시나제 저해 활성을 나타낸 것으로 사료되어진다.

\section{감사의 글}

본 연구는 중소기업기술혁신개발사업 연구비 지원(과제번 호 S1059417)에 의해 이루어졌으며 이에 감사 드립니다.

\section{References}

1. Agrawal, R. C. and T. Beohar. 2010. Chemopreventive and anticarcinogenic effects of Momordica charantia extract. Asian Pac. J. Cancer Prev. 11, 371-375.

2. Astrup, T. and S. Mullertz. 1991. The fibrin plate method for estimating fibrinolytic activity. Arch Biochem Biophys. 40, 346-351.

3. Bidlack, W. R. and A. L. Tappel. 1973. Damage to microsomal membrane by lipid peroxidation. Lipids 8, 177-178.

4. Blois, M. S. 1958. Antioxidant determination by the use of a stable free radical. Nature 26, 1199-1204.

5. Cabanes, J., S. Chazarra, and F. Garcia-Carmona. 1994. Kojic acid, a cosmetic skin whitening agent, is a slow binding inhibitor of catecholase activity of tyrosinase. J. Pharm Pharmacol. 46, 982-985.

6. Cha, J. Y., B. S. Jeon, J. W. Park, G. G. Shin, B. K. Kim, H. K. Kim, and Y. S. Cho. 2004. Hypoglycemic effect of mushroom fermented milk in streptozotocin-induced diabetic rats. J. Life Sci. 14, 676-682.

7. Cha, J. Y., Y. T. Kim, H. S. Kim, and Y. S. Cho. 2008. Antihyperglycemic effect of stem bark powder from paper mulberry (Broussonetia kazinoki Sieb) in type 2 diabetic Otsuka Long-Evans Tokushima fatty rats. J. Med Food 11, 499-505.

8. Cha, J. Y., H. Y. Ahn, K. E. Eom, B. K. Park, B. S. Jun, and Y. S. Cho. 2009. Antioxidative activity of Aralia elata shoot and leaf extracts. J. Life Sci. 19, 652-658.

9. Cha, J. Y., Y. S. Kim, H. Y. Ahn, K. E. Eom, B. K. Park, and Y. S. Cho. 2009. Biological activity of fermented silkworm powder. J. Life Sci. 19, 1468-1477.

10. Cha, J. Y., H. J. Yang, J. J. Jeong, W. S. Seo, J. S. Park, M. Ok, and Y. S. Cho. 2010. Tyrosinase inhibition activity and 
antioxidant capacity by fermented products of some medicinal plants. J. Life Sci. 20, 940-947.

11. Chen, C. R., Y. W. Liao, L. Wang, Y. H. Kuo, H. J. Liu, W. L. Shih, H. L. Cheng, and C. I. Chang. 2010. Cucurbitane triterpenoids from Momordica charantia and their cytoprotective activity in tert-butyl hydroperoxide-induced hepatotoxicity of HepG2 cells. Chem Pharm Bull. (Tokyo) 58, 1639-1642

12. Chien, C. C., M. L. Tsai, C. C. Chen, S. J. Chang, and C. H. Tseng. 2008. Effects on tyrosinase activity by the extracts of Ganoderma lucidum and related mushrooms. Mycopathologia 166, 117-120.

13. Choi, B. H. 1993. Status of buckwheat genetic resources in East Asia. Korean J. Breed 24, 293-301.

14. Choi, Y. M., J. B. Gu, M. H. Kim, and J. S. Lee. 2008. Antioxidant and antiproliferative activities of methanolic extracts from thirty Korean medicinal plants. Food Sci. Biotechnol. 17, 1235-1239.

15. Chung, D. W. 1992. Study on antioxidative substances of Ganoderma lucidum Korean J. Food Sci. Technol. 24, 497-503.

16. Daka, M. D. and C. P. Semba. 1995. Thrombolytic therapy in venous occlusive disease. J. Vsac. Interv. Radil. 6, 73-77.

17. Duncan, D. B. 1959. Multiple range and multiple $F$ test. Biometrics 1, 1-42.

18. Fabjan, N., J. Rode, I. J. Wang, Z. Zhang, and I. Kreft. 2003. Tartary buckwheat (Fagopyrum tataricum Gaertn.) as a source of dietary rutin and quercitrin. J. Agric. Food Chem 51, 6452-6455.

19. Han, M. J., E. A. Bae, K. Y. Rhee, and D. H. Kim. 1996. Effect of mushroom on the growth of intestinal lactic acid bacteria. Korean J. Food Sci. Technol. 28, 947-952.

20. Harinantenaina, L., M. Tanaka, S. Takaoka, M. Oda, O. Mogami, M. Uchida, and Y. Asakawa. 2006. Momordica charantia constituents and antidiabetic screening of the isolated major compounds. Chem Pharm Bull. (Tokyo) 54, 1017-1021.

21. Heo, J. S., J. Y. Cha, H. W. Kim, H. Y. Ahn, K. E. Eom, S. J. Heo, and Y. S. Cho. 2010. Biological materials and biological activity in the extracts of leaf, stem mixture and root from Angelica gigas Nakai. J. Life Sci. 20, 750-759.

22. Hikino, H., C. Konno, Y. Mirin, and T. Hayashi. 1985. Isolation and hypoglycemic activity of ganoderan A and B, glycans of Ganoderma lucidum fruit bodies. Planta Med 4, 339-340.

23. Jeon, B. S., J. W. Park, B. K. Kim, H. K. Kim, T. S. Jung, J. R. Hahm, D. R. Kim, Y. S. Cho, and J. Y. Cha. 2005. Fermented mushroom milk-supplemented dietary fibre prevents the onset of obesity and hypertriglyceridaemia in Otsuka Long-Evans Tokushima fatty rats. Diabetes Obes Metab. 7, 709-715.

24. Jia, Z., M. Tang, and J. Wu. 1999. The determination of flavonoid contents in mulberry and their scavenging effects on superoxide radicals. Food Chem 64, 555-559.

25. Ju, Y. S. and B. S. Ko. 2002. Screening of insulin-like substances from traditional herbs of diabetes prescription in Donguibogam. J. Korean Soc. Agric. Chem Biotechnol. 45, 47-52.
26. Jung, S. W., N. K. Lee, S. J. Kim, and D. S. Han. 1995. Screening of tyrosinase inhibitor from plants. Korean J. Food Sci. Technol. 27, 891-896.

27. Kabir, Y., S. Kimura, and T. Tamura. 1988. Dietary effect of Ganoderma lucidum mushroom on blood pressure and lipid levels in spontaneously hypertensive rats (SHR). J. Nutr. Sci. Vitaminol. (Tokyo) 34, 433-438.

28. Kim, E. Y., I. H. Baik, J. H. Kim, S. R. Kim, and M. R. Rhyu. 2004. Screening of the antioxidant activity of some medicinal plants. Korean J. Food Sci. Technol. 36, 333-338.

29. Kim, I. J., H. K. Kim, J. H. Jong, Y. K. Jeong, and C. H. Ryu. 2002. Study of functional Chungkukang contain fibrinolytic enzyme. J. Life Sci. 12, 357-362.

30. Kim, J. E., S. I. Joo, J. H. Seo, and S. P. Lee. 2009. Antioxidant and a-glucosidase inhibitory effect of tartary buckwheat extract obtained by the treatment of different solvents and enzymes. J. Korean Soc. Food Sci. Nutr. 38, 989-995.

31. Kim, J. H. and Y. S. Kim. 1998. Purification and characterization of fibrinolytic enzyme from Armillariella mellea. Korean J. Mycol. 26, 583-588.

32. Kim, J. H. 2000. Purification and characterization of fibrinolytic enzyme from Tricholoma saponaceum Korean J. Mycol. 28, 60-65.

33. Kim, S. J., M. Y. Heo, K. H. Bae, S. S. Kang, and H. P. Kim. 2003. Tyrosinase inhibitory activity of plant extract (III): Fifty Korean indigenous plants. J. Applied Phamacol. 11, 245-248.

34. Lee, D. S., J. G. Kim, and S. H. Lee. 2006. Inhibition of a -glucosidase activity by quercetin. Korean J. Microbiol. Biotechnol. 34, 368-372.

35. Lee, J. H., N. K. Kim, D. Y. Lee, and C. H. Lee. 1999. Protective effect of selected amino acids and food extracts on ethanol toxicity decrement in rat liver. Korean J. Food SCi. Technol. 31, 802-808.

36. Lee, K. E. and H. Y. Chung. 2000. Inhibitory effect of extracts from Parmelia austrosinensis and P. praesorediosa and postprandial hyperglycemia. Korean J. Food Nutr. 13, 134-138.

37. Lin, J. M., C. C. Lin, M. F. Chen, T. Ujiie, and A. Takada. 1995. Radical scavenger and antihepatotoxic activity of Ganoderma formosanum, Ganoderma lucidum and Ganoderma neo-japonicum J. Ethnopharmacol. 47, 33-41.

38. Masamoto, Y., H. Ando, Y. Murata, Y. Shimoishi, M. Tada, and K. Takahata. 2003. Mushroom tyrosinase inhibitory activity of esculetin isolated from seeds of Euphorbia lathyris L. Biosci. Biotechnol. Biochem 67, 631-634.

39. Oh, H. S., J. H. Kim, and M. H. Lee. 2003. Isoflavone contents, antioxidative and fibrinolytic activities of red bean and mung bean. Korean J. Soc. Food Cookery Sci. 19, 263-270.

40. Park, G. S., S. H. An, K. H. Choi, J. S. Jeoung, C. S. Park, and M. A. Choi. 2000. Preparation of the functional beverages by fermentation and its sensory characteristics. Korean J. Soc. Food Sci. 16, 663-669.

41. Park, J. S., K. W. Hyun, S. B. Seo, S. M. Cho, C. H. Yoo, and J. S. Lee. 2003. Detection of platelet aggregation inhibitors and fibrinolytic substances from mushrooms. Korean J. Mycol. 31, 114-116. 
42. Sato, M., N. Ramarathnam, Y. Suzuki, M. Takeuchi, and H. Ochi. 1996. Varietal differences in the phenolic content and superoxide radical scavenging potential of wines from different sources. J. Agric. Food Chem 44, 37-41.

43. Sekar, D. S., K. Sivagnanam, and S. Subramanian. 2005. Antidiabetic activity of Momordica charantia seeds on streptozotocin induced diabetic rats. Pharmazie. 60, 383-387.

44. Seto, S. W., T. Y. Lam, H. L. Tam, A. L. Au, S. W. Chan, J. H. Wu, P. H. Yu, G. P. Leung, S. M. Ngai, J. H. Yeung, P. S. Leung, S. M. Lee, and Y. W. Kwan. 2009. Novel hypoglycemic effects of Ganoderma lucidum water-extract in obese/diabetic $(+\mathrm{db} /+\mathrm{db})$ mice. Phytomedicine 16, 426-436.

45. Shinde, J., T. Taldone, M. Barletta, N. Kunaparaju, B. Hu, S. Kumar, J. Placido, and Z. S. William. 2008. a-Glucosidase inhibitory activity of Syaygium cumini (Linn.) Skeels seed kernel in vitro and in Goto-Kakizaki (GK) rats. Carbohydr. Res. 343, 1278-1281.

46. Sumi, H., H. Hamada, H. Tsushima, H. Mihara, and H. Muraki. 1978. A novel fibrinolytic enzyme (Nattokinase) in the vegetable che in Natto: a typical and popular soybean food in the Japanese diet. Experimentia 43, 1110-1111.

47. Swain, T., W. E. Hillis, and M. Oritega. 1959. Phenolic constituents of Ptunus domestica. I. Quantitative analysis of phenolic constituents. J. Sci. Food Agric. 10, 83-88.

48. Tabuchi, M., M. Ozaki, A. Tamura, N. Yamada, T. Ishida, M. Hosoda, and A. Hosono. 2003. Antidiabetic effect of Lactobacillus GG in streptozotocin-induced diabetic rats. Biosci. Biotechnol. Biochem 67, 1421-1424.

49. Thirunavukkarasu, M. and F. G. Pries. 1983. Synthesis of a-amylase and a-glucosidase by membrane bound ribosomes from Bacillus licheniformis. Biochem Biophys. Res. Commun. 114, 677-682.
50. Uebanso, T., H. Arai, Y. Taketani, M. Fukaya, H. Yamamoto, A. Mizuno, K. Uryu, T. Hada, and E. Takeda. 2007. Extracts of Momordica charantia suppress postprandial hyperglycemia in rats. J. Nutr. Sci. Vitaminol. (Tokyo) 53, 482-488.

51. Vile, G. F. and R. M. Tyrrell. 1995. UVA radiation-induced oxidative damage to lipid and protein in vitro and in human skin fibroblast is dependent on iron and singlet oxygen. Free Radical Biol. Med 18, 721-730.

52. Wang, F. S., H. Cai, J. S. Yang, Y. M. Zhang, C. Y. Hou, J. Q. Liu, and M. J. Zhao. 1997. Studies on the ganoderic acid, a new constituents from the fruiting body of Ganoderma lucidum (Fr.) Karst. Yao Xue Xue Bao 32, 447-450.

53. Wong, S. F., B. Holliwell, R. Richimond, and W. R. Skowroneck. 1981. The role of superoxide and hydroxyl radical in the degradation of hyaluronic acid induced by metal ions and by ascorbic acid. J. Inorganic. Biochem 14, 127-134.

54. Yadav, H., S. Jain, and P. R. Sinha. 2008. Oral administration of dahi containing probiotic Lactobacillus acidophilus and Lactobacillus casei delayed the progression of streptozotocin-induced diabetes in rats. J. Dairy Res. 75, 189-195.

55. Yang, S. A., N. K. Im, and I. S. Lee. 2007. Effects of methanolic extract from Salvia miltiorrhiza Bunge on in vitro antithrombotic and antioxidative activities. Korean J. Food Technol. 39, 83-87.

56. Yao, Y., F. Shan, J. Bian, F. Chen, M. Wang, and G. Ren. 2008. D-chiro-inositol-enriched tartary buckwheat bran extract lowers the blood glucose level in KK-Ay mice. J. Agric Food Chem 56, 10027-10031.

57. Zhu, Q. V., R. M. Hackman, X. X. Jodilensunsa, R. R. Holt, and C. L. Keen. 2002. Antioxidative activities of Oolong tea. J. Agric. Food Chem 50, 6229-6234.

초록 : 영지버섯, 여주, 쓴메밀 및 혼합 시료의 메탄올 추출물의 생리활성

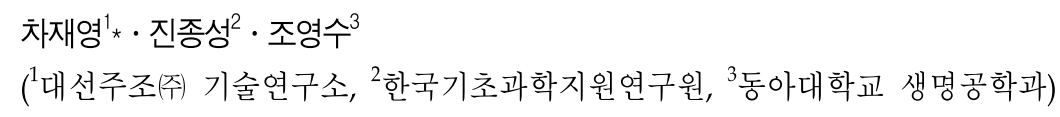

영지버섯, 여주, 쓴메밀 및 이들 혼합 시료의 $70 \%$ 메탄올 추출물을 이용하여 생리활성물질(폴리페놀 화합물 및 플라보노이드) 농도와 항산화(DPPH radical 소거 활성, 생체막 지질과산화, $\mathrm{Fe} / \mathrm{Cu}$ 환원력), a-glucosidase 저 해, tyrosinase 저해 및 항혈전 활성에 대하여 검토하였다. 추출 수율과 폴리페놀 화합물 및 플라보노이드의 함량 은 혼합 추출물에서 가장 높았다. 또한 혼합 추출물에서 a-glucosidase 저해, tyrosinase 저해, 항산화, 환원력 및 항혈전 활성은 혼합 추출물에서 가장 높았으며, 이러한 효과는 처리 농도 의존적 이였다. 이상의 실험 결과에서 영지버섯, 여주, 쓴메밀의 혼합 메탄올 추출물은 폴리페놀 화합물과 플라보노이드를 많이 함유함으로서 높은 aglucosidase 저해 및 항산화 활성과 관련성이 높아 보여 항당뇨 건강 기능성식품의 소재 개발에 활용될 가능성이 높아 보인다. 